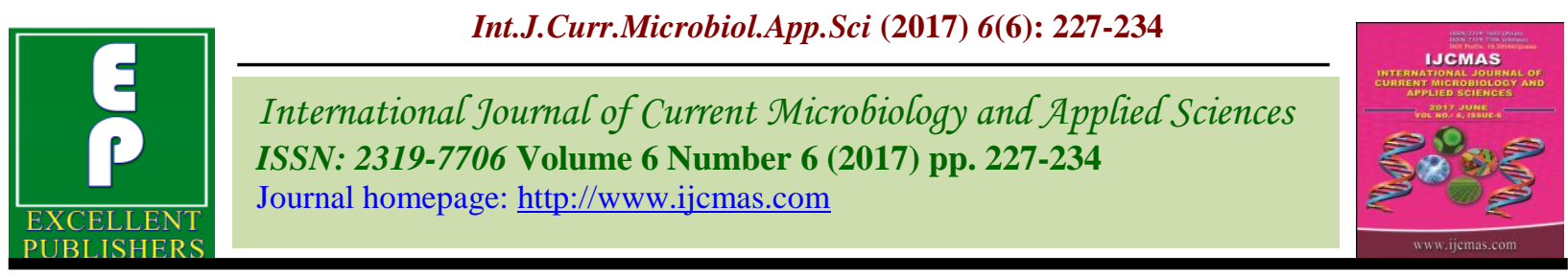

Original Research Article

https://doi.org/10.20546/ijcmas.2017.606.027

\title{
Biodiversity of Lichens in Lambasingi, A.P., India
}

\section{Sai Kumari*, Laxmana Rao Goje and Neeti saxena}

Mycology and Plant Pathology Lab, Department of Botany, University College For women, Koti, Osmania University, Hyderabad, India

*Corresponding author

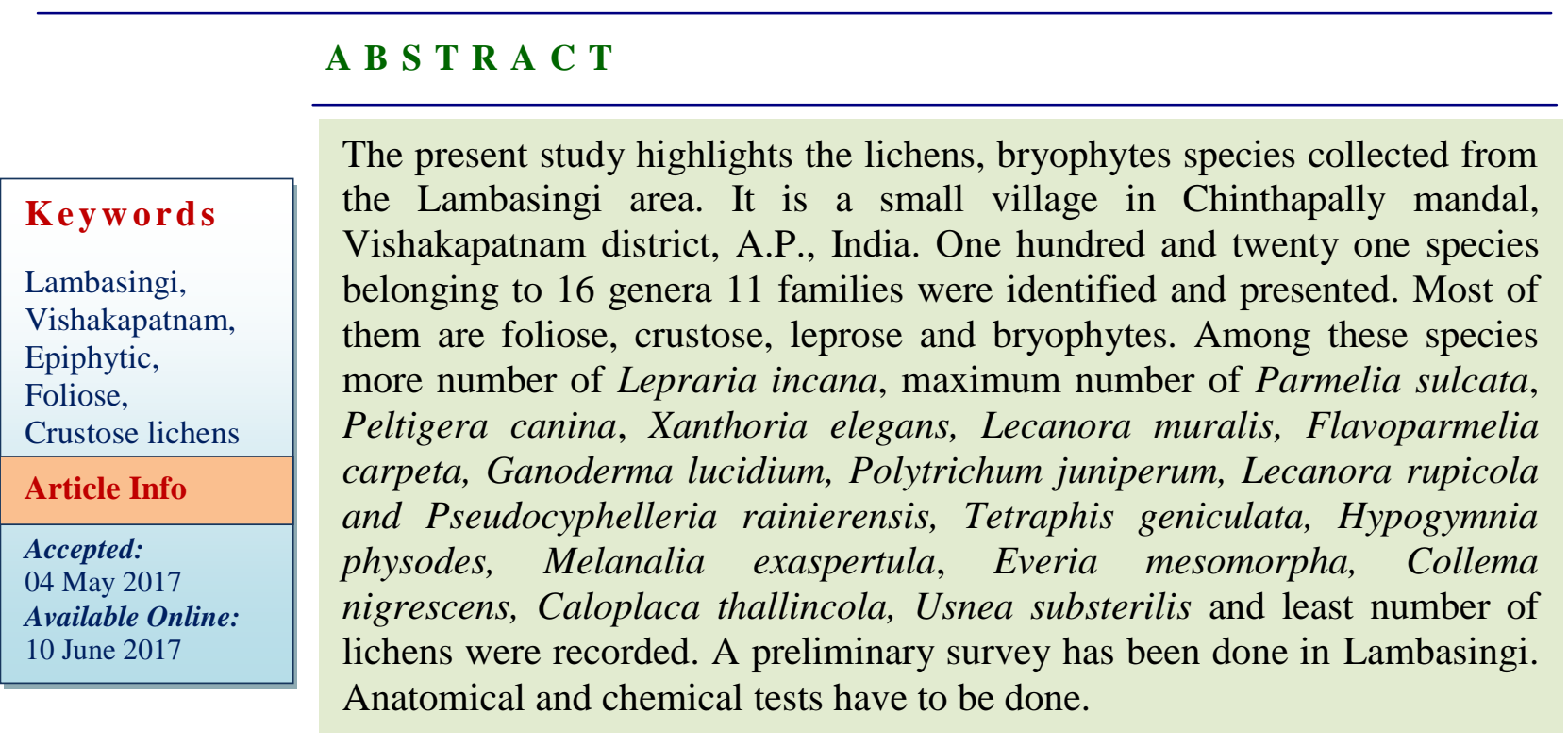

\section{Introduction}

Lambasingi is a small village in the Chinthapally mandal of Vishakapatnam district of Andhrapradesh, India. It is called as Khashmir of Andhrapradesh. It is 1000 meters above from the sea level and the temperatures are as low as $0^{\circ} \mathrm{C}$ in December- January. It is an agency area, $101 \mathrm{~km}$ far from Vishakapatnam on road. Sunlight appears only after 10am and there is heavy snowfall in winter with thick fog. The location is 17049' 10 '” $\mathrm{N}$ and 82029'26'E.

Lichens are a symbiotic association of an algal partner (phyco-biont) and a fungal partner myco-biont (Ahmadijan, 1993). The fungus act as the house for the alga, giving it shelter from the weather. The fungus makes up $90 \%$ of whole lichen. Alga contains chlorophyll it can produce food by the process of photosynthesis (Marijana Kosanić, Branislav Ranković., 2010). The symbiotic relationship of fungus and alga helps lichens adapt to life in all kinds of places. Some lichens grow on dead wood, on tree bark or on the ground and some are grow on rocks (Taylor et al., 1995). All lichens need some water to grow but they also exist in dry conditions for long time due to its absorbent nature. When rainfall adds moisture to the air they absorb most of the water than their body weight. Most of them are growing in spring and rainy season. When the weather is dry 
lichens may go dormant stage. They cannot live in the pollution area due to atmosphere contains sulphur dioxide they may damage the chlorophyll in algal partner.

Lichens synthesize various bioactive components, which sometimes constitute more than $30 \%$ of the dry mass of talus (Galun, 1988). Although there are about 20,000 species of them around the world, and even they make $8 \%$ of the terrestrial ecosystems, their biological activity and biological components are not distinguished very much (Toma et al., 2001). Various biological activities of some lichens and their components are known, such as antiviral, anti-tumor, anti-inflammatory, analgetic, antipyretic, anti-proliferative, antiprotozoal (Lawrey, 1986; Halama et al., 2004; Huneck, 1999). Besides, many species are used for human nutrition, animal nutrition, for getting colors, perfumes, alcohol and in the medicine industry (Kirmizigul et al., 2003). Lichens have also, for hundreds of years, been used in many European countries as a cure for stomach diseases, diabetes, cough, pulmonary tuberculosis, wounds curing, dermatological diseases (Baytop, 1999; Huneck, 1999). The usage of some lichens in the traditional medicine for many years was later justified by numerous researches which proved their antimicrobal activity (Cansaran et al., 2006; Choudhary et al., 2005; Gulluce et al., 2006; Rankovic et al., 2007).

The present work is a preliminary survey of lichen flora of Vizag agency area, as it has been unexplored.

\section{Materials and Methods}

The collection of lichens was made from the 28th to 31st December 2016 only at Lambasingi near areas. The collection was done in the deep forest for future studies. The images were taken from their original locations. Only morphological study was made, anatomical and chemical study has to be done.

\section{Results and Discussion}

One hundred and twenty one species belonging to 16 genera 11 families were collected from the forest. The species are Pseudocyphellaria rainierensis, Tetraphis geniculata, Hypogymnia physodes, Melanelia exasperatula, Parmelia sulcata, Peltigera canina, Xanthoria elegans, Evernia mesomorpha, Collema nigrescens, Caloplaca thallincola, Usnea substerilis, Lecanora muralis, Flavoparmelia carpeta, Lepraria incana, Lecanora dispersa, Ganoderma lucidium, Polytrichum juniperum, Lecanora rupicola were identified.

Most of the lichens are foliose, crustose, a few are leprose lichens. Ganoderma, bryophytes were reported. They are present either on rocks (or) on bark of trees. Their appearance is white to brown with yellowish green (or) orange tint.

\section{Lichen species}

\section{Pseudocyphellaria rainierensis}

Old growth specklebelly lichen is a distinctive macrolichen characterized by large, draping curatin lobes. A pale greenish - blue upper surface, rogged, lobulate to isidiate lobe margins and a pale lower surface scattered small white spots (Goward, 1996).

\section{Hypogymnia physodes}

Monk' s-hood lichen is variable in form, usually forming flattened or somewhat erect closely attached, gray to blue-gray, long or short smooth lobes which are often irregular branched at the tips. Lobe tips are hollow, usually inflated, and hood-like, producing pale green powdery vegetative granules on the inside. The lower surface is wrinkled, 
black, lacking attachment outgrowths. The fungal layer is white, and fruiting bodies are rare (Rankovic et al 2008).

\section{Melanelia exasperatula}

Lustrous brown lichen has closely attached, often oily shiny and centrally dull, olive-green to olive-brown, smooth, flat to slightly wrinkled lobes, which are sometimes raised at the tips, or reflected at the margins. No powdery or granular vegetative structures are present; instead small bumps on the upper surface enlarge into inflated, hollow, shiny, club shaped or barrel-shaped structures, with simple or occasionally forked tips, which are miniature vegetative structures.

The lower side is tan to dark brown, having many attachment structures. Fruiting bodies are very uncommon (Brodo et al., 2000).

\section{Parmelia sulcata}

Hammered shield lichen has blue or ashy gray, lobes, becoming almost brown in open locations, but becoming a light green when moistened. The lobes are elongated with entire or notched margins, with a network of sharp raised ridges and depressions with numerous small white dots caused by breaks in the upper surface, showing white fungal strands breaking through on the surface. Round or elongate powdery vegetative structures can often be seen along these ridges or on lobe margins.

The underside is black, with numerous simple attachment structures, which become branched upon maturity. Fruiting bodies are rare, but occasionally produced directly or on short stalks upon the upper surface; margins entire, or occasionally with small powdery vegetative structures. The disks are flat and dull brown (De Vries et al., 1998).

\section{Peltigera canina}

The upper surface of scaledog-lichen has smooth, dull gray, greenish brown to brown, more or less wavy lobes which tend to become crisp upon aging, and with a thin wooly covering on the lobe tips. Minute small flat regeneration bodies can develop along stress cracks and margins. The pale undersurface has a network of slightly raised light brown to brown veins, becoming darker towards the center, and with simple rather long thread-likeout growth. Fruiting bodies are uncommon (Johnson et al., 1995).

\section{Xanthoria elegans}

Elegant sunburst lichen is a showy species, forming almost circular patches, with radiating, irregular branched, pale yellowish orange to dark red-orange lobes. The lobes are closely attached, rounded, and narrow, lacking vegetative structures. The lower protective surface is white without attachment bodies. Fruiting bodies are sessile or slightly stalked, yellow to orange, with flat or convex discs the same colour as the lichen body (Thomson, 1997).

\section{Evernia mesomorpha}

This yellowish green semi pendent or tufted lichen, has irregularly thick, abundantly divided, angular, and longitudinally wrinkled to partly flattened, soft and pliable branches. Abundant coarse masses of yellowish to grayish vegetative structures occur on the angular ridges. No fruiting bodies are present. The inner fungal layer is white and loose.

\section{Collema nigrescens}

This is a foliose, small to medium-sized, gelatinous cyanolichen. The thallus is $2-5 \mathrm{~cm}$ diameter, but sometimes up to $10 \mathrm{~cm}$; lobes are broadly rounded, 5-10 $\mathrm{mm}$ wide. It is 
gelatinous when wet, dark olive to brownish or black, sometimes with yellowish brown areas. Upper surface with "conspicuous blister-like pustules and ridges" (Brodo et al., 2001). Isidia usually absent, but sometimes with globular to slightly oblong or flattened isidia, marginal and laminal, up to $0.2 \mathrm{~mm}$ wide. Soredia lacking, Apothecia very common and numerous, often crowded, to 1 $\mathrm{mm}$ diameter, disk brownish red, without pruina. Spores 5-13 celled, colorless, needleshaped with elongate pointed ends, straight or spirally curved, 50-100 $\mu \mathrm{m}$ long x 3-4.5 $\mu \mathrm{m}$ wide Photobiont cyanobacterial (Nostoc). (Brodo et al., 2001; Nash et al., 2004; McCune and Geiser, 1997).

\section{Caloplaca thallincola}

Thallus egg yellow to bright yellow -orange and rather shiny, not pruinose, placodioid with marginal lobes usually long and finger like, but lobing sometimes less evident on rough rock surfaces, apothecia with orange discs, rather scattered in the center of the thallus. Generally common on hard, silicaceous, coastal rocks (Ester Gaya et al., 2008).

\section{Usnea substerilis}

Embossed beard is a rather small, usually $25 \mathrm{~mm}$ long and wide, greenish or strawyellow colored, erect, pendent species. The main stem has many rather tufted non-inflated branches, distinctly covered with cylindrical bumps, which are lacking on the branches, and has a narrow basal dark zone. Branches are smooth, appearing at right angles to the main stem, bearing copious small, raised vegetative structures, containing a very fine whitish powdery substance in localized masses, and often mixed with easily detached peg-like structures. Fruiting bodies are absent.

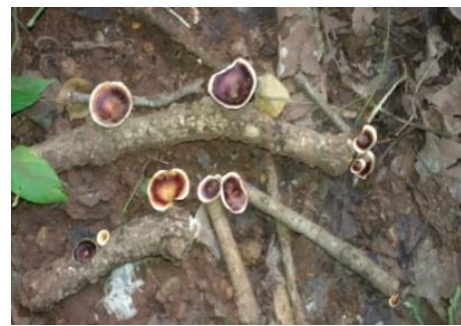

Ganoderma lucidium

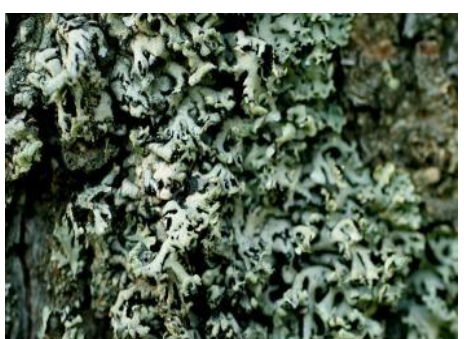

Hypogymnia physodes

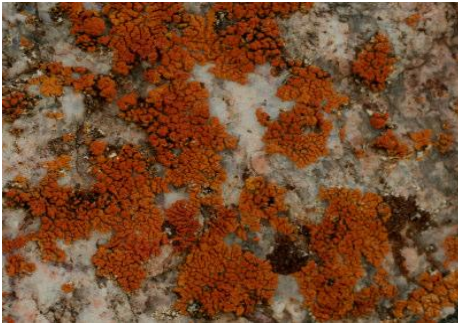

Xanthoria elegans

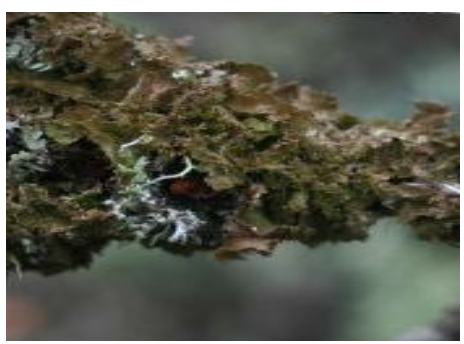

Melanelia exasperatula

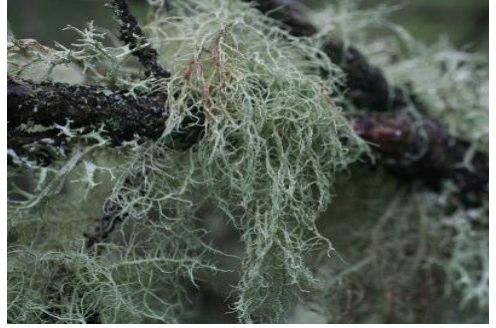

Usnea substerilis

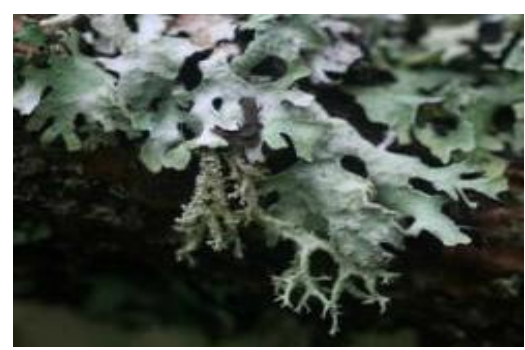

Palmeria sulcata 


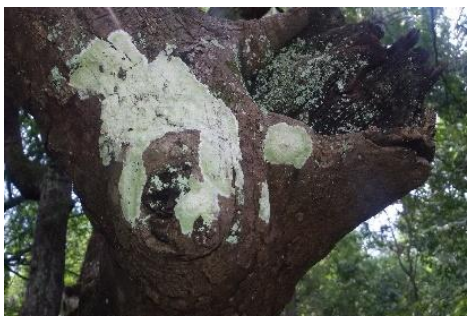

Lacanora rupicola

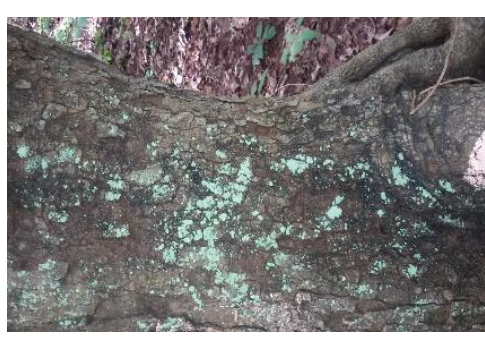

Lepraria incana

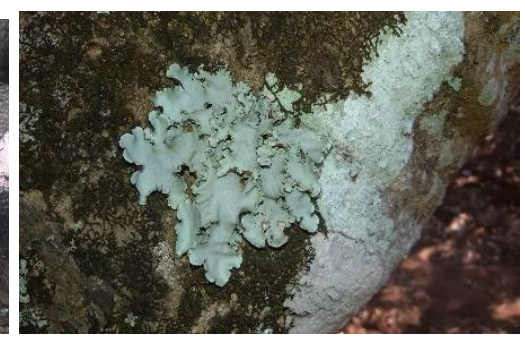

Flavoparmelia carpeta
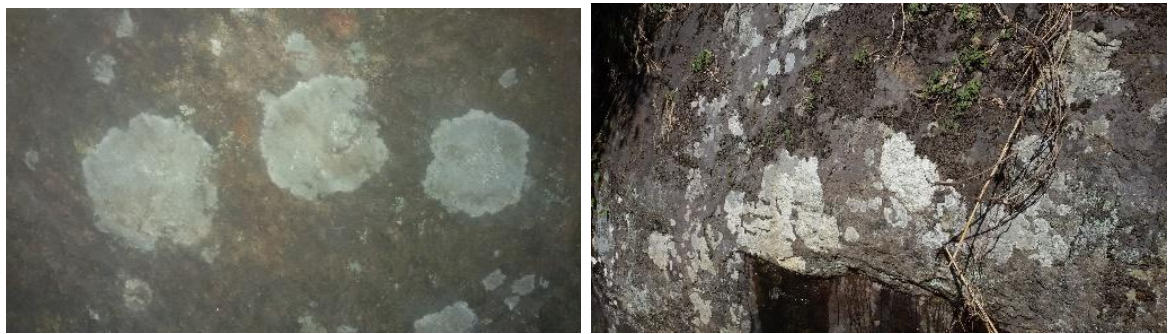

Lecanora muralis sps

\section{Lecanora muralis}

Thallus crustose, placodioid, closely adnate, forming orbicular patches upper surface grayish green, glossy; central lobes areolate, marginal parts plane, edges thin pruinose; lower surface ecorticate; apothecia sessile, lecanorine type, exciple dense and intact when young, and disc plane, but when mature, exciple laciniate, disc protrude, yellowish brown to orange (Xin Li Wei et al., 2007).

\section{Flavoparmelia carpeta}

This is common green shield lichen, is a medium to large foliose lichen that has a very distinctive pale yellow green upper cortex when dry.

The rounded lobes, measuring 3-8 mm wide usually have patches of granular soredia arising from pustules. The lobes of thallus may be smooth, but quite often have a wrinkled appearance. The lower surface is black except for a brown margin, rhizomes attached to the lower surface are black and unbranched (Ioana Vicol, 2013).

\section{Lepraria incana}

Thallusleprose-sorediate, thick or thin, lacking well-defined lobes, whitish green to greenish grey, diffuse and forming extensive, irregularly spreading patches to $50 \mathrm{~cm}$ wide, less commonly in small, irregularly roundish, \pm delimited colonies.

Three to five $\mathrm{mm}$ wide that eventually coalesce; medulla absent; hypo thallus very well developed, white or rarely pale greyish white, forming a thick weft covered with soredia except for a soredia-free zone at the thallus margins, composed of branched and occasionally anastomosing hyphae 2.5-4 $\mu \mathrm{m}$ thick with smooth or rough walls

Soredia farinose, dispersed over the hypo thallus or forming a thick, continuous layer, \pm roundish, 16-40 $\mu \mathrm{m}$ wide, surrounded by an incomplete 'wall', sometimes aggregated in round to slightly elongated clumps (consoredia) to $80 \mu \mathrm{m}$ wide, very rarely with a few projecting hyphae to $15 \mu \mathrm{m}$ long; photobiont chlorococcoid, with individual cells 5-8 (-10) $\mu \mathrm{m}$ diametre (Gintaras Kantvilas, 2006). 


\section{Lecanora dispersa}

Thallus thin and disappearing or immersed, leaving apothecia mostly scattered on the substrate surface, apothecia small, usually $1 \mathrm{~mm}$ diameter, with discs variable in color but generally grey brown, margins pruinose. They are very common on nutrient rich rocks becoming a ubiquitous urban species.

\section{Ganoderma lucidium}

It is an oriental fungus, large dark mushroom, with a glossy exterior and a woody texture.it is seen throughout the world in temperate and sub- tropical locations. In nature it grows at the base and stumps of deciduous trees, especially maple.

\section{Lecanora rupicola}

Crustose, continuousor rimose aerolate to verrucose, prothallus, not visible or white areoles. Flat, thin or thick, opaque or glossy, ecorticate surface, whitish gray to gray green to greenish white, smooth, epruinose, with an indistinct margin, esorediate Apothecia. Sub immersed when young, sessile. Generally appears on the rocks and on the trees.

\section{Bryophytes}

\section{Polytrichum juniperum}

Juniper hair cap moss is most common on dry, exposed sites. It typically grows in open woods and forests and old fields. It is rare in moist soils, although it is found occasionally on moist sites such as stream banks and moist woods. Juniper hair cap moss stems are upright and unbranched in habit, growing from 0.4 to 4 inches $(1-10 \mathrm{~cm})$ tall. The stems are a shiny bluish-green, resembling common juniper (Juniperus communis) leaves in color and shape. Stems are usually densely packed. Juniper hair cap moss is heterothallic, with male and female stems on separate plants Juniper hair cap moss's leathery leaves are 4 to $8 \mathrm{~mm}$ long. They spread widely when moist, becoming narrower and more upright when dry. Leaf margins curve into the stem when dry, which probably reduces water loss and enhances juniper hair cap moss's ability to photosynthesize on xeric sites.

\section{Tetrphis geniculata}

Commonly called as four toothed mass. Occurs on the cut (or) broken ends (or) lower half of large decay rotten logs (or) stumps. Occassionally on peaty banks. This is a small green to reddish- brown tufts. Leaves are ovate, acute, 1-2mm long with costa ending below the apex. It is autoicious with the capsule born a $7-17 \mathrm{~mm}$ long seta that is twisted, geniculate near the middle and papillose near the bend. The capsule is narrowly cylindric, yellow brown $1.5-3.0 \mathrm{~mm}$ long with 4 large peristome teeth (Zacharia and Magombo, 2003).

Lichens occur from sea level to high alpine elevations, in a very wide range of environmental conditions, and can grow on almost any surface (Speer et al., 1997). Lichens are abundant growing on bark, leaves, mosses, on other lichens (Sharnoff, Stephen, 2014). Different kinds of lichens have adapted to survive in some of the most extreme environments on Earth: arctic tundra, hot dry deserts, rocky coasts, and toxic slag heaps. They can even live inside solid rock, growing between the grains.

One hundred and twenty one species belong to 16 genera and 11 families were presented in this survey. Among all these species Lepraria incana was recorded as highest number of lichen. Parmelia sulcata, Peltigera canina, Xanthoria elegans, Lecanora muralis, Flavoparmelia carpeta, Ganoderma lucidium, Polytrichum juniperum, Lecanora rupicola 
was reported as maximum number of lichens. Pseudocyphelleria rainierensis, Tetraphis geniculata, Hypogymnia physodes, Melanalia exaspertula, Everia mesomorpha, Collema nigrescens, Caloplaca thallincola, Usnea substerilis, was recorded as least number of lichens in the deep forest of Lambasingi and the near areas.

In conclusion Lambasingi and near forest areas are favorable to the biodiversity of the lichens. These areas are agency areas, no pollution and less population areas. Lichens are the indicators to the pollution less atmosphere. Although lichens are very helpful to the atmosphere, humans and animals as in many forms.

\section{Acknowledgement}

I would like thank to UGC for providing the NON-NET fellowship through the Department of Botany, University College of Science, Osmania University, Hyderabad Telangana state, India.

\section{References}

Taylor, T.N., Hass, H., Remy, W., Kerp, H. (1995): The oldest fossil lichen.Nature, 378: 244-244.

Thomson, J.W. 1997. American Arctic Lichens 2-The Micro lichens. The University of Wisconsin Press, Madison, Wisconsin, U.S.A.

Toma, N., Ghetea, L., Nitu, R., Corol, D.I. (2001): Progress and perspectives in the biotechnology of lichens. Roum. Biotechnol. Lett, 6: 1-15.

Xin Li Wei,Keon Seon Han, You Mi Lee, Young Jin Koh and Jae-Seoun Hur New Record of Lecanora muralis (Lichenized Fungus) in South Korea Mycobiology 35(2): 45-46 (2007).

Zacharia L. K. Magombo.The Phylogeny of Basal Peristomate Mosses: Evidence from cpDNA, and Implications for Peristome Evolution Systematic Botany (2003), 28(1): pp. 24-38.

Ahmadjian, V. (1993): The lichen symbiosis. New York. John Wiley and Sons, 1250.

Baytop, T. (1999): Therapy with Medicinal plants in Turkey (Past and Present) Istanbul, University, Istanbul, 1-233.

Brodo, I., Sylvia Sharnoff, and Stephen Sharnoff. 2000. Lichens of North America. New Haven, CT: Yale University Press. 795 pp.

Brodo, I.M., S.D. Sharnoff, and S. Sharnoff. 2001. Lichens of North America. Yale University Press, New Haven, U.S.A.

Cansarana, D., Kahya, D., Yurdakulol, E., Akakol, O. (2006): Identification and quantitation of usnic acid from the lichen Usnea species of Anatolia and Anti- microbial activity. Z. Naturforsch. C, 61: 773-776.

Choudhary, M.I., Azizuddin Jalil, S., Att-urRahman. (2005): Bioactive Phenolic compounds from a medicinal lichen, Usnea longissima. Phytochemistry, 66:2346-2350.

De Vries, B. and C.D.Bird.1998 Lichen list from Cypress Hills Interprovincial Park, Saskatchewan. Typewritten report. Unpublished.

Ester Gaya, Pere Navarro-Rosine'Sb, Xavier lllmona, Ne'stor Hladun, Franc, ois Lutzonia Phylogenetic reassessment of the Teloschistaceae (lichen-forming Ascomycota, Lecanoromycetes) mycological research $112\left(\begin{array}{llll}2 & 0 & 0 & 8\end{array}\right) 5$ $28-546$.

Galun, M. (1988): CRC Handbook of Lichenology. CRC Press, Boca Raton, Florida, 95-107.

Gintaras Kantvilas and Martin Kukwa A new species of Lepraria (lichenized Ascomycetes) from Tasmania's wet forests. Muelleria 23: 3-6 (2006). 
Goward, T. 1996. COSEWIC status report on the old growth speckle-belly Pseudocyphellaria rainierensis in Canada. Committee on the status of endangered wildlife in Canada. Ottawa.1-36pp.

Gulluce, M., Aslan, A., Sokmen, M., Sahin, F., Adiguzel, A., Agar, G., Sokmen, A. (2006): Screening the antioxidant and antimicrobial properties of the Lichens Parmelia saxatilis, Platismatia glauca, Ramalina pollinaria, Ramalina polymorpha and Umbilicaria nylanderiana.

Phytomedicine, 13: 515-521.

Halama, P., Van Haluwin, C. (2004): Antifungal activity of lichen extracts and lichenic acids. BioControl, 49: 95-107.

Huneck, S. (1999): The significance of lichens and their metabolites. Naturwissenschaften, 86: 559-570.

Ioana Vicol Distribution of Flavoparmelia caperata (L.) Hale in Romania Analele Ştiinţifice ale Universităţii Al. ICuza"Iaşi s. II a. Biologie vegetala, 2013, 59, 2: 65-73.

Johnson, D.L., Kershaw, A. MacKinnon, and J.Pojar, with contributions from $\mathrm{T}$. Goward and D. Vitt. 1995. Plants of the Western Boreal Forest and Aspen Parkland. Lone Pine. Edmonton, Alberta, Canada.

Kirmizigul, S., Koz, Ö, Anil, H., IÇLI, S. (2003): Isolation and Structure Elucidation of Novel Natural Products from Turkish Lichens. Turk. J. Chem. 27: 493-500.
Lawrey, J.D. (1986): Biological role of lichen substances. Bryologist, 89: 11-122.

Lichens Cladonia furcata, Parmelia caperata, Parmelia pertusa, Hypogymnia physodes and Umbilicaria polyphylla. British Jornal of Biomedical Science, 64: 143-148.

Marijana Kosanić, Branislav RankovicScreening of Anti-microbial Activity of some lichen species in vitro. Department of Biology, Faculty of Science, University of Kragujevac, J. Sci. 32 (2010) 65-72.

McCune, Bruce and Linda Geiser. 1997. Macro lichens of the Pacific Northwest. Corvallis, OR: Oregon State University Press. 386 p.

Ranković, B., Mišić, M. and Sukdolak, S. The antimicrobial activity of substances derived from the lichens Physcia aipolia, Umbilicaria polyphylla, Parmelia caperataand Hypogymnia physodes. World J Microbiol Biotechnol (2008) 24: 1239. Doi: 10.1007/s11274-007-9580-7.

Rankovic, B., Misic, M., Sukdolak, S. (2007): Antimicrobial activity of the

Sharnoff, Stephen (2014) Field Guide to California Lichens, Yale University Press.

Speer, Brian R; Ben Waggoner (May 1997). "Lichens: Life History and Ecology".

University of California Museum of Paleontology. Retrieved 28 April 2015.

\section{How to cite this article:}

Sai Kumari, D., Laxmana Rao Goje and Neeti Saxena. 2017. Biodiversity of Lichens in Lambasingi, A.P., India. Int.J.Curr.Microbiol.App.Sci. 6(6): 227-234.

doi: https://doi.org/10.20546/ijcmas.2017.606.027 